\title{
Amelioration of Gamma-hexachlorocyclohexane (Lindane) induced renal toxicity by Camellia sinensis in Wistar rats
}

\author{
W. L. N. V. Vara Prasad ${ }^{1}$, Ch. Srilatha ${ }^{1}$, N. Sailaja ${ }^{2}$, N. K. B. Raju ${ }^{3}$ and N. Jayasree ${ }^{1}$
}

1. Department of Veterinary Pathology, College of Veterinary Science, Sri Venkateswara Veterinary University, Tirupati, Andhra Pradesh, India; 2. Department of Veterinary Pathology, College of Veterinary Science, Sri Venkateswara Veterinary University, Proddatur, Andhra Pradesh, India; 3. Department of Veterinary Anatomy, NTR College of Veterinary Science, Sri Venkateswara Veterinary University, Gannavaram, Andhra Pradesh, India.

Corresponding author: W. L. N. V. Vara Prasad, e-mail: prasad.mudaliyar@gmail.com, CS: ch.srilatha1965@yahoo.co.in, NS: sailajapath@gmail.com, NKBR: nkbraju@gmail.com, $\mathrm{NJ}$ : jayasreerdysvvu@gmail.com

Received: 02-08-2016, Accepted: 27-10-2016, Published online: 30-11-2016

doi: 10.14202/vetworld.2016.1331-1337 How to cite this article: Vara Prasad WLNV, Srilatha Ch, Sailaja N, Raju NKB, Jayasree N (2016) Amelioration of gamma-hexachlorocyclohexane (lindane) induced renal toxicity by Camellia sinensis in Wistar rats, Veterinary World, 9(11): 1331-1337.

\begin{abstract}
Aim: A study to assess the toxic effects of gamma-hexachlorocyclohexane $(\gamma-\mathrm{HCH})$ (lindane) and ameliorative effects of Camellia sinensis on renal system has been carried out in male Wistar rats.

Materials and Methods: Four groups of rats with 18 each were maintained under standard laboratory hygienic conditions and provided feed and water ad libitum. $\gamma-\mathrm{HCH}$ was gavaged at $20 \mathrm{mg} / \mathrm{kg}$ b.wt. using olive oil as vehicle to Groups II. C. sinensis at $100 \mathrm{mg} / \mathrm{kg}$ b.wt. was administered orally in distilled water to Group IV in addition to $\gamma-\mathrm{HCH} 20 \mathrm{mg} / \mathrm{kg}$ b.wt. up to 45 days to study ameliorative effects. Groups I and III were treated with distilled water and C. sinensis $(100 \mathrm{mg} / \mathrm{kg}$ b.wt.), respectively. Six rats from each group were sacrificed at fortnight intervals. Serum was collected for creatinine estimation. The kidney tissues were collected in chilled phosphate buffer saline for antioxidant profile and in also $10 \%$ buffered formalin for histopathological studies.
\end{abstract}

Results: $\gamma$-HCH treatment significantly increased serum creatinine and significantly reduced the renal antioxidative enzymes catalase, superoxide dismutase, and glutathione peroxidase. Grossly, severe congestion was noticed in the kidneys. Microscopically, kidney revealed glomerular congestion, atrophy, intertubular hemorrhages, degenerative changes in tubular epithelium with vacuolated cytoplasm, desquamation of epithelium and urinary cast formation. A significant reduction in serum creatinine levels, significant improvement in renal antioxidant enzyme activities and near to normal histological appearance of kidneys in Group IV indicated that the green tea ameliorated the effects of $\gamma-\mathrm{HCH}$, on renal toxicity.

Conclusion: This study suggested that $C$. sinensis extract combined with $\gamma-\mathrm{HCH}$ could enhance antioxidant/detoxification system which consequently reduced the oxidative stress thus potentially reducing $\gamma-\mathrm{HCH}$ toxicity and tissue damage.

Keywords: Camellia sinensis, gamma-hexachlorocyclohexane, kidney.

\section{Introduction}

Lindane, the gamma-isomer of hexachlorocyclohexane $(\gamma-\mathrm{HCH})$, is one of the oldest synthetic pesticides still in use worldwide. Lindane still is more commonly used to eradicate insects in agriculture and to treat lice infestation in humans, poultry, and livestock [1]. Its persistence in the environment, high mammalian toxicity, and resistance to biodegradation led to a ban or restricted use in many developed and developing countries, and this pesticide has become widely distributed in ecosystems and is now considered a global pollutant [2]. $\gamma-\mathrm{HCH}$ has a deteriorative effect on fauna and flora by inducing oxidative stress.

Copyright: Vara Prasad, et al, Open Access. This article is distributed under the terms of the Creative Commons Attribution 4.0 International License (http://creativecommons.org/licenses/ by/4.0/), which permits unrestricted use, distribution, and reproduction in any medium, provided you give appropriate credit to the original author(s) and the source, provide a link to the Creative Commons license, and indicate if changes were made. The Creative Commons Public Domain Dedication waiver (http:// creativecommons.org/publicdomain/zero/1.0/) applies to the data made available in this article, unless otherwise stated.
$\gamma-\mathrm{HCH}$ is an inducer of the mixed function oxidase system such as cytochrome $\mathrm{B}_{5}$, nicotinamide adenine dinucleotide phosphate cytochrome P-450 reductase, and nicotinamide adenine dinucleotide - cytochrome C-reductase, which results in increased superoxide radical formation [3].

In India, the rich and diversified flora provides a valuable storehouse of medicinal plants. Homeopathic and phytotherapeutic remedies in veterinary medicine have gained an interest due to increasing demands on the quality of meat and milk products such as the requirements for producing good organic food [4]. Camellia sinensis commonly known as green tea is one of the most widely consumed beverages in the world, and many of its medicinal properties have been widely explored. Green tea polyphenols have demonstrated significant antioxidant [5], anticarcinogenic [6], and anti-inflammatory [7] properties.

Therefore, this study was aimed to evaluate a protective effect of green tea extract against $\gamma-\mathrm{HCH}$ induced renal damage by biochemical and histopathological analysis. 


\section{Materials and Methods}

\section{Ethical approval}

The study protocol was approved from the Institutional Animal Ethics Committee constituted in accordance with the rules and guidelines of the Committee for the Purpose of Control and Supervision of Experiments and Animals, India (CPCSEA 722/06).

\section{Chemicals}

Lindane $(\gamma$-isomer of $\mathrm{HCH})$ was purchased from Sigma-Aldrich Pvt. Ltd., Bengaluru, India. The C. sinensis (green tea) whole leaf extract powder (methanolic extract containing $99.9 \%$ polyphenol) with product Code No. P/SVU/CASI-01 was procured from Chemiloids Company, Vijayawada, Andhra Pradesh state.

\section{Experimental animals}

Male albino Wistar rats weighing between 150 and $200 \mathrm{~g}$ each were used for this experiment. They were procured from Sri Venkateswara Agencies, Bengaluru (REG NO: 237/99/CPCSEA). The rats were maintained in a controlled environment under standard conditions of temperature $\left(28 \pm 2^{\circ} \mathrm{C}\right)$ and humidity with an alternating light and dark cycle. The rats were fed with commercially available pelleted rat chow and water ad libitum. After a week of acclimatization, rats were divided into control and test groups of 18 rats each. Lindane $(20 \mathrm{mg} / \mathrm{kg})$ dissolved in olive oil and green tea $(100 \mathrm{mg} / \mathrm{kg})$ dissolved in Water, were administered to rats (appropriate amounts dissolved in fixed volume of $0.3 \mathrm{ml}$ ) for 45 days by oral administration.

\section{Experimental design}

The rats were divided into four groups of 18 rats in each. Group I served as control $(0.3 \mathrm{ml}$ of water by oral administration), Group II rats were treated with lindane $(20 \mathrm{mg} / \mathrm{kg}$ b.wt. by oral administration), Group III rats were treated with green tea (100 mg/kg b.wt. dissolved in water by oral administration), Group IV rats were co-treated with lindane (20 mg/kg b.wt.) and green tea (100 mg/kg b.wt.), first the animals were treated with lindane followed by green tea $15 \mathrm{~min}$ later.

Six rats from each group were anesthetized by exposing to diethyl ether and then sacrificed by cervical decapitation. Blood was collected; serum was separated and used for renal marker assay. The kidney tissues were dissected out, washed in ice-cold saline, patted dry, and weighed. A small portion of the kidney tissue was stored in $10 \%$ formalin for histopathological examination. From the remaining tissue, about $100 \mathrm{mg}$ tissue of kidney samples homogenized in chilled $0.1 \mathrm{M}$ Tris-HCl buffer in Potter-Elvehjem Teflon homogenizer. The homogenates were used for biochemical investigation.

\section{Histopathology}

A small portion of kidney tissue from the control and experimental animals was fixed in $10 \%$ neutral buffered formalin and processed by standard procedure for paraffin embedding and serial sections of about $5 \mu$ size cut and were stained with hematoxylin and eosin.

\section{Measurement of creatinine}

The activities of serum creatinine were estimated in blood serum using Prietest Robonik semi-automatic biochemical analyzer with commercial biochemical kits (Span Diagnostics). The results were expressed as $\mathrm{mg} / \mathrm{dl}$ for serum creatinine.

\section{Measurement of antioxidants}

The kidney tissue homogenates were used for the assay of superoxide dismutase (SOD), catalase (CAT), and glutathione peroxidase (GPx). CAT activity is determined by monitoring the decrease in absorbance spectrophotometrically at $240 \mathrm{~nm}$ due to decomposition of $\mathrm{H}_{2} \mathrm{O}_{2}$, the difference in extinction coefficient per unit time is a measure of the CAT activity [8]. Superoxide is an intermediate in the autooxidation of pyrogallol which occurs at $\mathrm{pH} 8.2$, the ability of SOD to inhibit the autooxidation of pyrogallol at $\mathrm{pH} 8.2$ provides the basis for enzymatic activity [9]. GPx reacts with $\mathrm{H}_{2} \mathrm{O}_{2}$ and reduced glutathione giving rise to oxidoreductase this will form a color complex with DTNB, the intensity of color development is directly proportional to amount of GPx present in the tissue [10]. The results were expressed as $\mathrm{mg} / \mathrm{g}$ of protein for SOD, $\mathrm{nM}$ of $\mathrm{H}_{2} \mathrm{O}_{2}$ decomposed $/ \mathrm{min} / \mathrm{mg}$ of protein for CAT and $\mu$ of glutathione utilized $/ \mathrm{min} /$ mg protein for GPx.

\section{Statistical analysis}

The values for all parameters were expressed as mean \pm standard error for six rats sacrificed from each group at fortnight intervals. Data were analyzed using one-way analysis of variance [11].

\section{Results}

Mean serum creatinine values of $\gamma-\mathrm{HCH}$ treated group (Group II) significantly $(\mathrm{p}<0.05)$ increased compared to control group (Group I) from $15^{\text {th }}$ to $45^{\text {th }}$ day of the experiment. Green tea ameliorated rats (Group IV) showed significant $(p<0.05)$ reduction in serum creatinine compared to Group II from $15^{\text {th }}$ to $45^{\text {th }}$ day of the experiment. Green tea ameliorated rats (Group IV) showed significantly $(\mathrm{p}<0.05)$ higher serum creatinine levels than control group from $15^{\text {th }}$ to $45^{\text {th }}$ day of the experiment. Green tea treated group (Group III) showed significant $(p<0.05)$ reduction in serum creatinine compared to the control group (Figure-1) from $15^{\text {th }}$ to $45^{\text {th }}$ day of the experiment.

A significant $(\mathrm{p}<0.05)$ reduction was observed in mean renal SOD, CAT and GPx activity from $15^{\text {th }}$ to day 45 of $\gamma-\mathrm{HCH}$ treated rats (Group II) compared to the control group (Group I). Green tea ameliorated rats (Group IV) showed significant $(p<0.05)$ increase in renal antioxidative enzymes compared to Group II from $15^{\text {th }}$ to $45^{\text {th }}$ day of experiment (Table-1). 
Table-1: The ameliorative effect of $C$. sinensis on $\gamma-\mathrm{HCH}$ induced changes in renal antioxidants $(n=18)$.

\begin{tabular}{|c|c|c|c|c|c|}
\hline $\begin{array}{l}\text { Biochemical } \\
\text { parameters }\end{array}$ & Days at sacrifice & Group I & Group II & Group III & Group IV \\
\hline \multirow[t]{3}{*}{ SOD $(\mathrm{mg} / \mathrm{g}$ of protein) } & $15^{\text {th }}$ day $($ Mean $\pm S D)$ & $16.62 \pm 0.132$ & $11.20 \pm 0.09^{a}$ & $16.01 \pm 0.29^{\mathrm{ab}}$ & $16.00 \pm 0.26^{\mathrm{ab}}$ \\
\hline & $30^{\text {th }}$ day (Mean $\left.\pm S D\right)$ & $17.00 \pm 0.34$ & $9.85 \pm 0.73 a$ & $15.90 \pm 0.07^{\mathrm{ab}}$ & $15.28 \pm 0.35^{\mathrm{ab}}$ \\
\hline & $45^{\text {th }}$ day (Mean $\left.\pm S D\right)$ & $16.5 .0 \pm 0.22$ & $7.42 \pm 0.086^{a}$ & $16.90 \pm 0.063^{b}$ & $14.05 \pm 0.96^{\mathrm{abc}}$ \\
\hline \multirow{2}{*}{$\begin{array}{l}\text { CAT (nM of } \mathrm{H}_{2} \mathrm{O}_{2} \\
\text { decomposed } / \mathrm{min} / \mathrm{mg} \text { of } \\
\text { protein) }\end{array}$} & $15^{\text {th }}$ day (Mean $\left.\pm S D\right)$ & $0.200 \pm 0.020$ & $0.170 \pm 0.0124^{a}$ & $0.220 \pm 0.014^{b}$ & $0.200 \pm 0.006^{b}$ \\
\hline & $\begin{array}{l}30^{\text {th }} \text { day }(\text { Mean } \pm S D) \\
45^{\text {th }} \text { day }(\text { Mean } \pm S D)\end{array}$ & $\begin{array}{l}0.223 \pm 0.010 \\
0.210 \pm 0.014\end{array}$ & $\begin{array}{l}0.135 \pm 0.008^{a} \\
0.075 \pm 0.032^{a}\end{array}$ & $\begin{array}{l}0.220 \pm 0.008^{b} \\
0.210 \pm 0.008^{b}\end{array}$ & $\begin{array}{c}0.180 \pm 0.0 .008^{\mathrm{abc}} \\
0.180 \pm 0.006^{\mathrm{abc}}\end{array}$ \\
\hline \multirow{3}{*}{$\begin{array}{l}\text { GPx ( } \mu \text { of glutathione } \\
\text { utilized/min/mg protein) }\end{array}$} & $15^{\text {th }}$ day (Mean $\left.\pm S D\right)$ & $28.01 \pm 1.86$ & $24.50 \pm 2.31^{a}$ & $26.40 \pm 1.01$ & $25.40 \pm 2.42$ \\
\hline & $30^{\text {th }}$ day (Mean $\pm S D$ ) & $27.50 \pm 0.68$ & $18.40 \pm 1.49^{a}$ & $27.90 \pm 1.35^{\mathrm{b}}$ & $23.01 \pm 2.62^{\mathrm{abc}}$ \\
\hline & $45^{\text {th }}$ day (Mean $\pm S D$ ) & $28.20 \pm 0.56$ & $13.20 \pm 2.43^{a}$ & $28.24 \pm 0.64^{b}$ & $20.51 \pm 1.30^{\mathrm{abc}}$ \\
\hline
\end{tabular}

arepresents asuperscript bearing group significantly differ from Group I $(p<0.001)$, brepresents bsuperscript bearing group significantly differ from Group II $(p<0.001)$, crepresents 'superscript bearing group significantly differ from Group III $(p<0.001)$, Mean values with different superscripts differ significantly $(p<0.05)$. ANOVA, SD=Standard deviation, $C$. sinensis=Camellia sinensis, $\gamma-\mathrm{HCH}=\gamma$-hexachlorocyclohexane, SOD=Superoxide dismutase, CAT=Catalase, $\mathrm{GPx}=$ Glutathione peroxidase

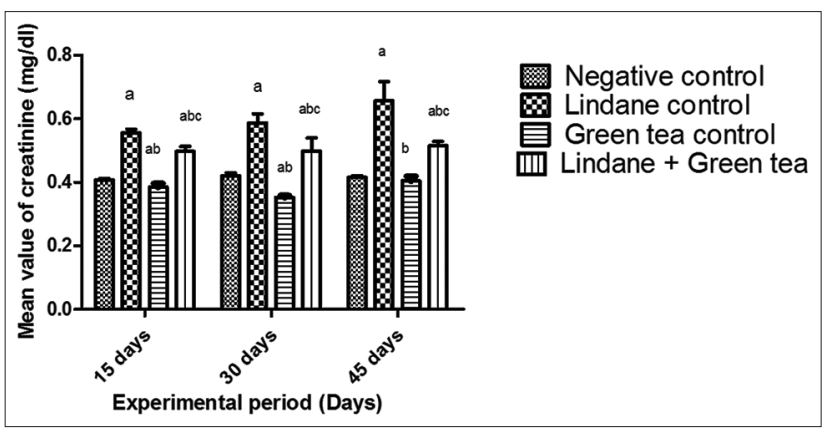

Figure-1: Mean values of serum creatinine $(\mathrm{mg} / \mathrm{dl})$ in rats of diffe rent experimental groups. $(n=18)$ Values bearing different superscripts in the figure are significantly different $(p<0.05)$.

Grossly, there were no observable lesions in kidneys of rats during the $15^{\text {th }}$ day of the experiment but severe congestion of kidneys was noticed by the end of the $30^{\text {th }}$ and $45^{\text {th }}$ day (Figure-2), and these changes were absent in the kidneys of the ameliorated group.

Kidney of $\gamma-\mathrm{HCH}$ treated animals at the end of the $15^{\text {th }}$ day of the experiment revealed congestion, mild glomerular congestion, and intertubular hemorrhages. Mild degenerative changes were noticed in the tubular epithelium (Figure-3) with swollen cells, condensed nuclei and loss of brush borders in proximal convoluted tubules and reduced lumen.

By the end of the $30^{\text {th }}$ day, kidneys of Group II rats revealed severe intertubular hemorrhages, increased bowman's capsular space in glomeruli (Figure-4), cystic dilatation of tubules, severe degenerative changes in tubular epithelium, diffuse infiltration of mononuclear cell (MNC) (Figure-5), and microgranuloma formation followed by necrosis and desquamation into lumen and cast formation.

At the end of the $45^{\text {th }}$ day, kidneys of Group II rats revealed severe corticomedullary congestion, glomerular congestion (Figure-6), and intertubular hemorrhages (Figure-7). Severe degenerative changes in tubular epithelium with vacuolated

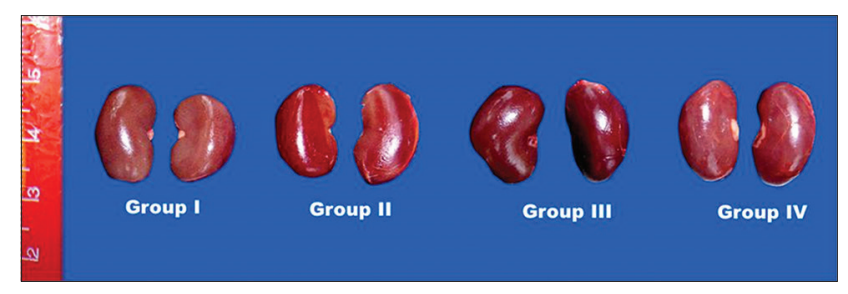

Figure-2: Congestion of gamma hexachlorocyclohexane treated rats kidney compared to other groups $45^{\text {th }}$ day of experiment.

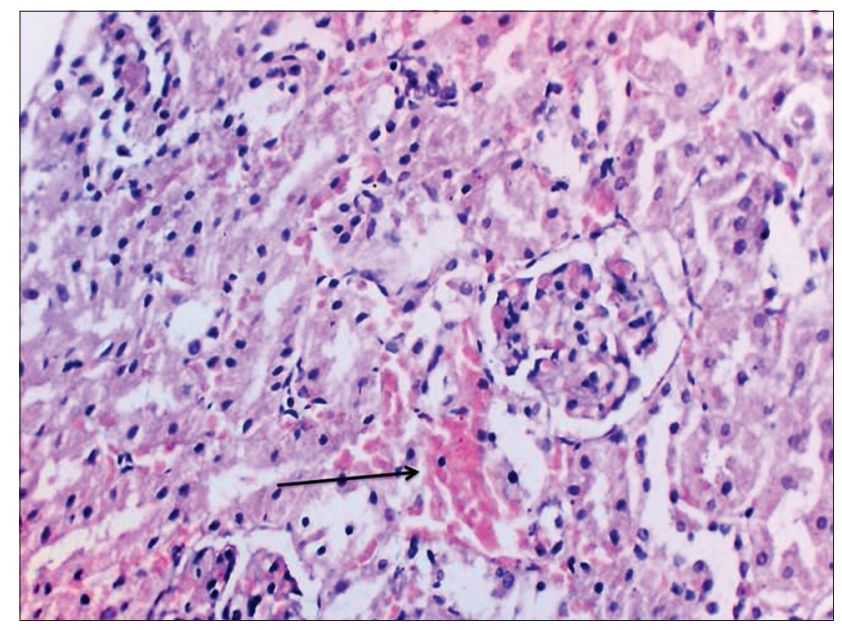

Figure-3: Degeneration of renal tubular epithelial cells and intertubular haemorrhages in kidney of gamma hexachlorocyclohexane treated rats $15^{\text {th }}$ day of experiment ( $\mathrm{H}$ and $\mathrm{E}, 400 \times)$.

cytoplasm (Figure-8) and desquamation of tubular epithelium leading to cast formation (Figure-9) and cystic dilatation of tubules (Figure-10) and necrosis were observed. Atrophic glomeruli and diffused areas of MNC infiltration were also observed (Figure-11).

Kidney sections of the green tea ameliorated rats revealed similar lesions as that of Group II till the end of the $15^{\text {th }}$ day. However, the $30^{\text {th }}$ day, the congested glomerulus, mild intertubular hemorrhages and mild degenerative changes in renal tubular epithelial cells (Figure-12) were noticed. Almost 


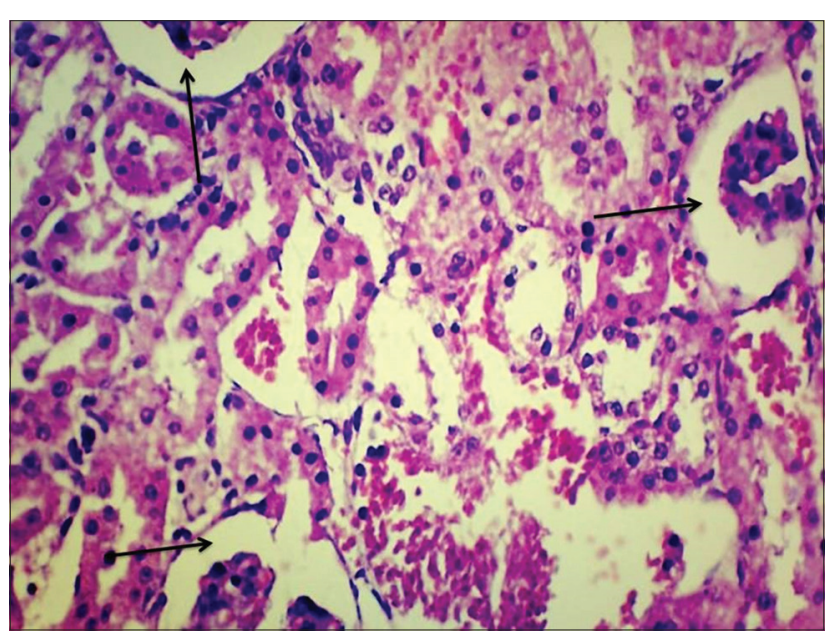

Figure-4: Increased bowman capsular spaces in kidney of gamma hexachlorocyclohexane treated rats $30^{\text {th }}$ day of experiment ( $\mathrm{H}$ and $\mathrm{E}, 400 \times)$.

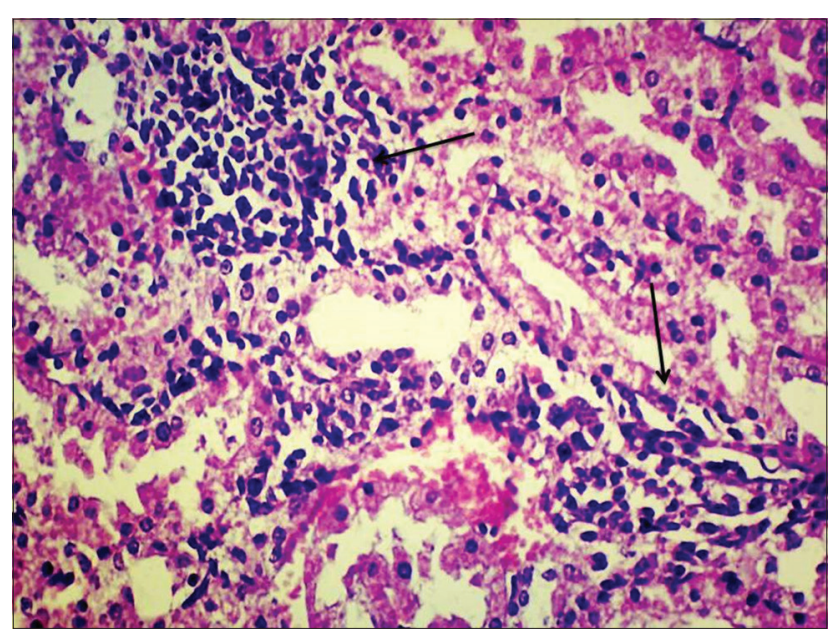

Figure-5: Severe degenerative changes in tubular epithelium and diffuse infiltration of mononuclear cell in kidney of gamma hexachlorocyclohexane treated rats $30^{\text {th }}$ day of experiment ( $\mathrm{H}$ and $\mathrm{E}, 400 \times)$.

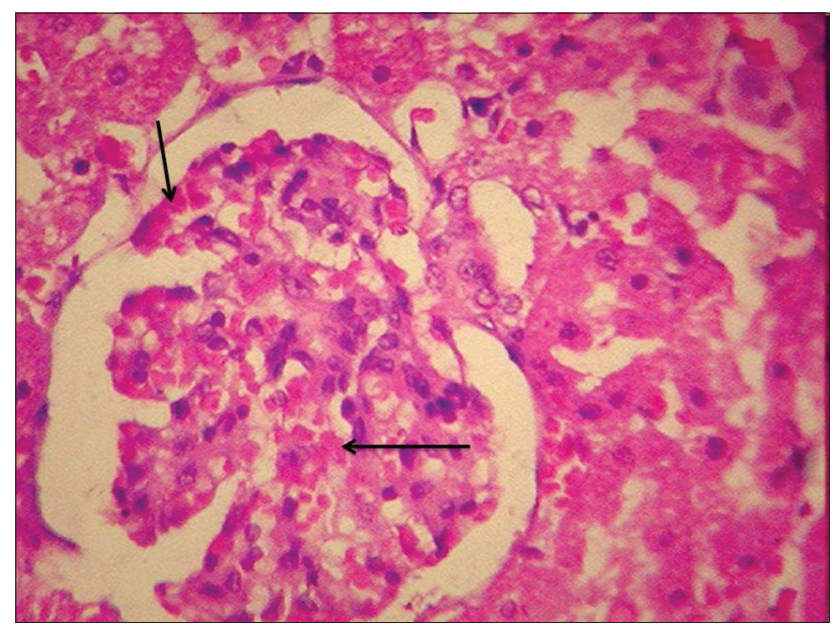

Figure-6: Glomerular congestion in kidney of gamma hexachlorocyclohexane treated rats $45^{\text {th }}$ day of experiment ( $H$ and $E, 400 \times)$.

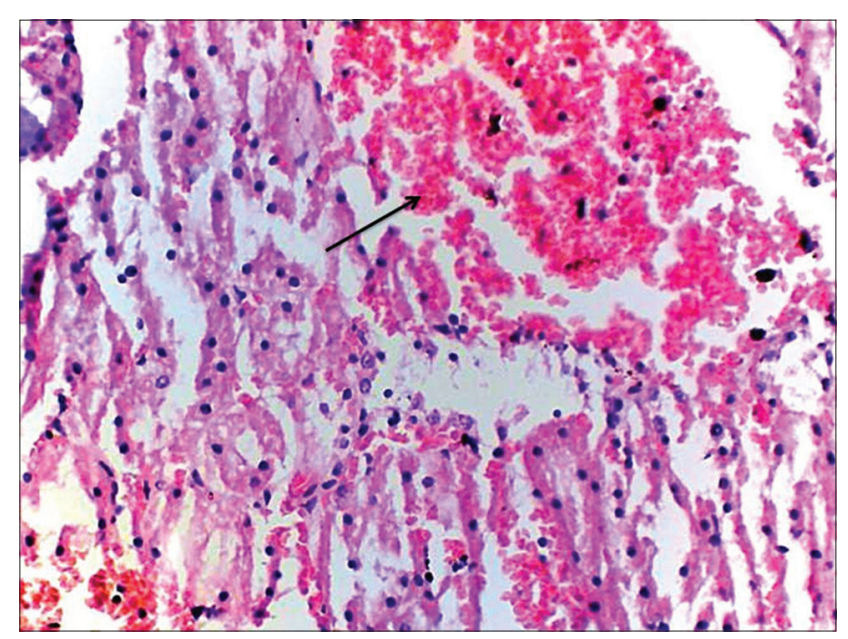

Figure-7: Severe intertubular hemorrhages in kidney of gamma hexachlorocyclohexane treated rats $45^{\text {th }}$ day of experiment ( $\mathrm{H}$ and $\mathrm{E}, 400 \times)$.

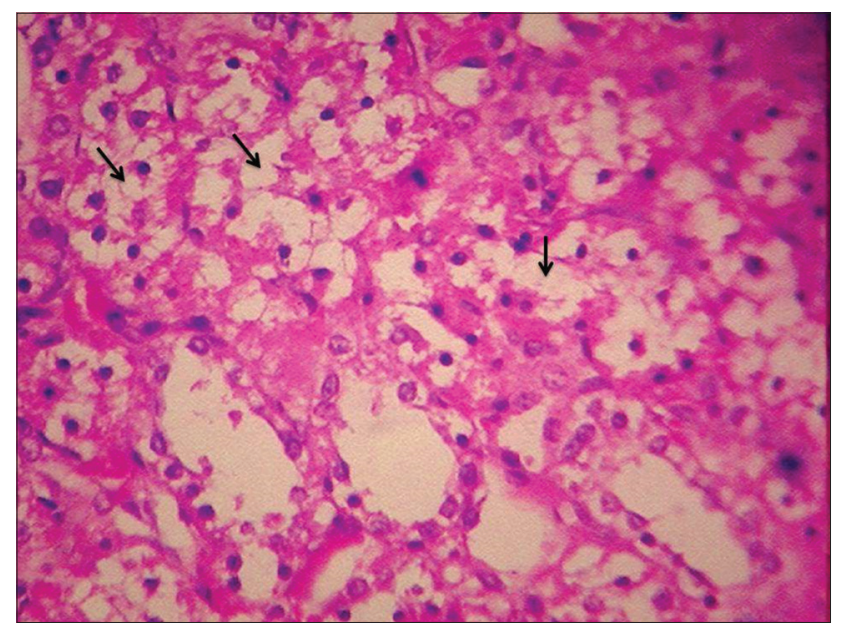

Figure-8: Severe degenerative changes in tubular epithelium with vacuolated cytoplasm in kidney of gamma hexachlorocyclohexane treated rats $45^{\text {th }}$ day of experiment ( $H$ and $E, 400 \times)$.

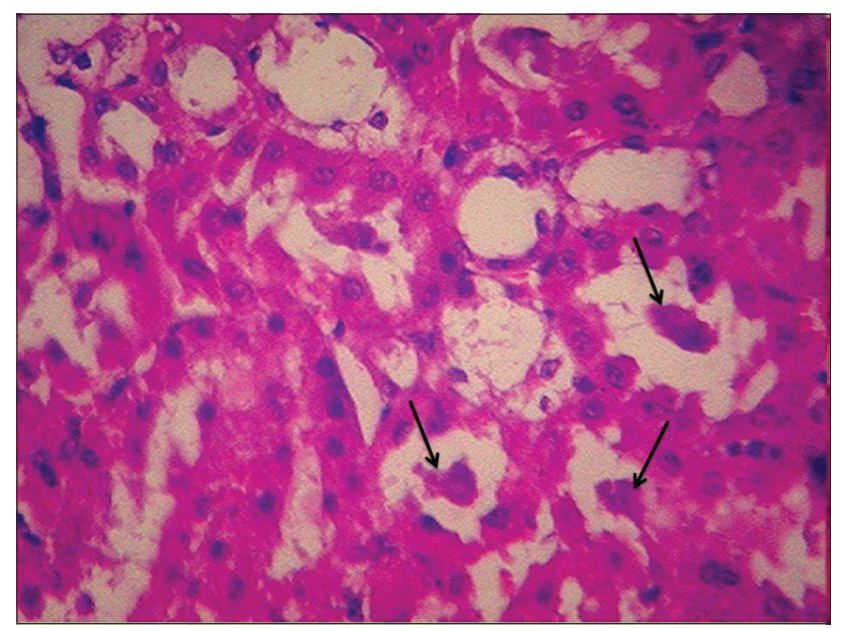

Figure-9: Severe desquamation of tubular epithelium leading to cast formation in kidney of gammahexachlorocyclohexane treated rats $45^{\text {th }}$ day of experiment ( $H$ and $E, 400 \times)$. 


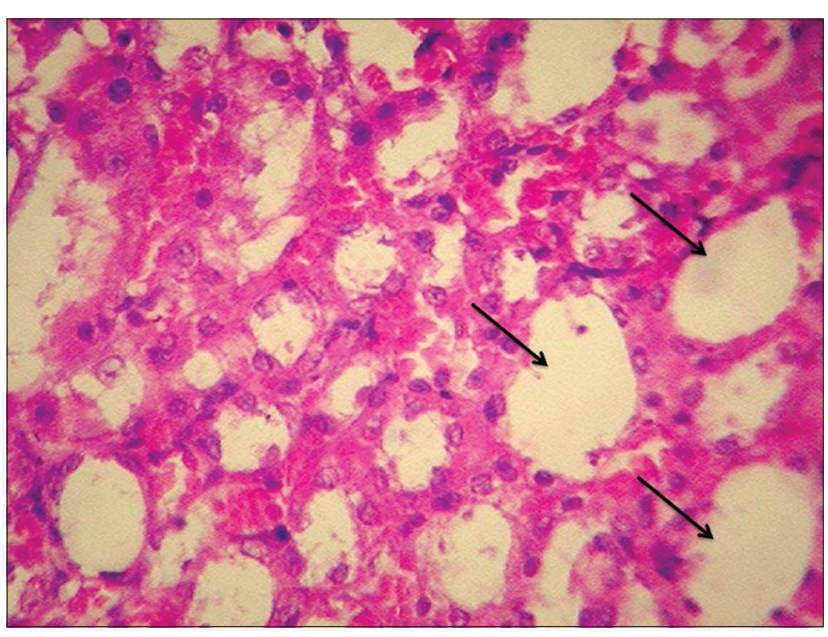

Figure-10: Cystic dilatation of tubules in kidney of gammahexachlorocyclohexane treated rats $45^{\text {th }}$ day of experiment ( $H$ and $E, 400 \times)$.

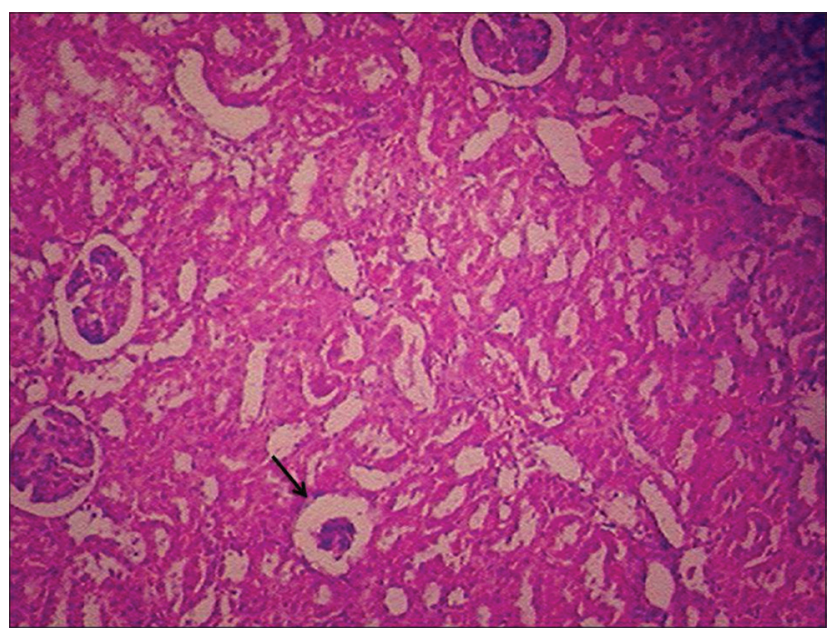

Figure-11: Atrophic glomeruli and necrotic changes in renal tubular epithelium of $\gamma$ hexachlorocyclohexane treated rats $45^{\text {th }}$ day of experiment ( $\mathrm{H}$ and $\left.\mathrm{E}, 100 \times\right)$.

near to normal appearance of kidneys was evident in all the animals by the end of the $45^{\text {th }}$ day (Figure-13).

\section{Discussion}

Serum creatinine levels of $\gamma-\mathrm{HCH}$ treated rats showed significant increase when compared to the control rats. Similar reports were made by previous author $[12,13]$ according to them serum concentration of endogenous creatinine was used as a measure of renal function because it is an easily measured by product of muscle metabolism that is excreted unchanged by the kidneys. The increased levels of serum creatinine in $\gamma$-HCH treated rats might be due to alteration in renal metabolism [14]. Significantly increased level of creatinine was observed in $\gamma-\mathrm{HCH}$ treated rats and is supported by renal damage evident microscopically and it might be due to oxidative stress induced by free radical interaction with the cell membrane, triggering the generation of reactive oxygen species (ROS) and other free radical intermediates and altering the levels of antioxidant molecules

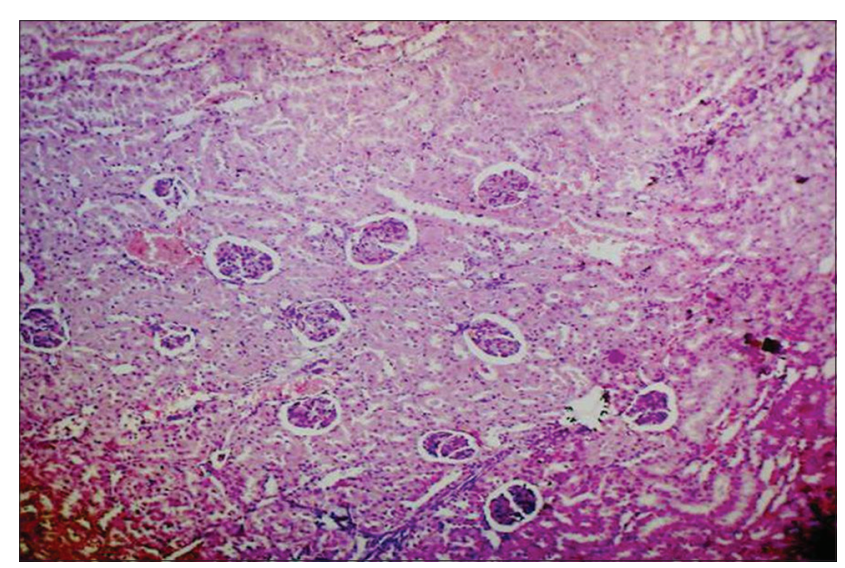

Figure-12: Kidney regained to its near to normal appearance in green tea treated rats by $30^{\text {th }}$ day of experiment ( $\mathrm{H}$ and $\mathrm{E}, 100 \times)$.

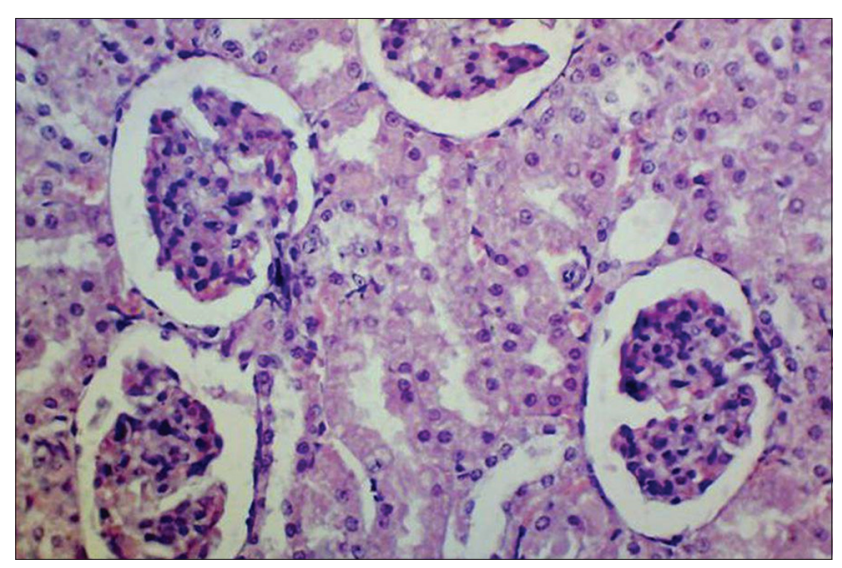

Figure-13: Kidney regained to its near to normal appearance in green tea treated rats by $45^{\text {th }}$ day of experiment ( $\mathrm{H}$ and $\mathrm{E}, 400 \times)$.

or enzymes such as CAT, SOD, and GPx [2]. Green tea ameliorated group showed significant decrease in serum creatinine values compared to $\gamma-\mathrm{HCH}$ treated group but failed to reach the levels in control group rats. This is in accordance to earlier reports $[15,16]$, who reported that green tea has polyphenols which have antioxidant property, scavenge a wide range of free radicals. Polyphenols prevent the metal catalyzed formation of radical species, antioxidant enzyme modulators, prevents oxidative damage and might have prevented the rise of serum creatinine levels.

A significant decrease in renal CAT, SOD and GPx was observed in $\gamma$ - $\mathrm{HCH}$ treated rats when compared to control group rats from the $2^{\text {nd }}$ week and continued up to the end of the experiment. These findings are in line with previous report [12]. The decrease in antioxidant enzyme activity might be due to $\gamma-\mathrm{HCH}$ induced generation of ROS [17] which further leads to oxidative damage of kidney and these were evidenced microscopically in the present study. A significant increase in CAT, SOD and GPx activities was noticed in ameliorated group when compared to $\gamma-\mathrm{HCH}$ treated rats, and the results are in accordance with previous authors $[15,16,18]$. This increase might 
be because of antioxidant activity of green tea. In this study, ameliorated group of rats showed significantly lower CAT, SOD and GPx activity than control group in all weeks indicated the amelioration to a certain extent though not completely ameliorating the toxic effect. These protective effects of green tea were also supported by histological restoration of normal renal architecture.

There was no significant change in kidneys of rats during the $15^{\text {th }}$ day of experiment but severe congestion of kidneys was noticed by the end of the $30^{\text {th }}$ and $45^{\text {th }}$ day, and these changes were absent in the kidneys of ameliorated group. These were in accordance to earlier reports [19].

Kidney revealed congested corticomedullary blood vessels, glomerular congestion, and intertubular hemorrhages microscopically. Degenerative changes in tubular epithelium with swollen cells, condensed nuclei, and loss of brush borders in proximal convoluted tubule were observed throughout the experiment. Increased bowman's capsular space in glomeruli, desquamation of renal tubular epithelium and urinary cast formation and diffuse intertubular infiltration of inflammatory cells were prominent in addition to the above changes in the $30^{\text {th }}$ and $45^{\text {th }}$ day of the experiment. Similar findings were reported by earlier authors $[16,19]$. Renal oxidative stress in this study is evidenced by a significant reduction in renal antioxidant enzymes CAT, SOD, and GPx. Creatinine which is considered as a renal marker is also significantly increased following $\gamma-\mathrm{HCH}$ administration. Histopathological examination of kidney of green tea ameliorated groups exhibited similar lesions but in milder form in some of the rats, but kidney regained its near to normal appearance by the end of the experiment. This might be due to antioxidant and free radical scavenging property of polyphenols of $C$. sinensis $[15,16]$. These protective effects of green tea were also supported by restoration of serum creatine levels and renal antioxidant enzymes.

\section{Conclusion}

The accumulation of $\gamma-\mathrm{HCH}$ in the kidneys was associated with oxidative stress and tissue injury as detected by histopathology. The treatment of rats with $C$. sinensis extract combined with $\gamma$-HCH could enhance antioxidant/detoxification system which consequently reduced the oxidative stress. The beneficial effect of $C$. sinensis in improving antioxidant status was associated with reduction of $\gamma-\mathrm{HCH}$ burden in kidneys thus potentially reducing $\gamma-\mathrm{HCH}$ toxicity and tissue damage.

\section{Authors' Contributions}

ChS, NS and NKBR planned, guided and supervised the entire research work. WLNVVP carried out the experimental work, laboratory analysis, histopathological analysis and data analysis. WLNVVP drafted the first manuscript with the help of NJ. ChS and NS revised the manuscript. All authors read and approved the final manuscript.

\section{Acknowledgments}

The results described in this paper were part of MVSc thesis of WLNVVP. The authors' wishes to acknowledge the faculty and staff of Department of Veterinary Pathology, College of Veterinary Science, Tirupati for their cooperation through-out the period of research study. Funds and facilities of department were utilized for conducting present study.

\section{Competing Interests} interests.

The authors declare that they have no competing

\section{References}

1. Sauviat, M.P., Colas, A. and Pages, N. (2002) Does lindane (gamma-hexachlorocyclohexane) increase the rapid delayed rectifier outward $\mathrm{K}+$ current $(\mathrm{IKr})$ in frog atrial myocytes? BMC Pharmacol., 2: 15-19.

2. Bano, M. and Bhatt, D.K. (2007) Neuroprotective role of a novel combination of certain antioxidants on lindane $(\mathrm{g}-\mathrm{HCH})$ induced toxicity in cerebrum of mice. J. Agric. Biol. Sci., 3: 664-669.

3. Junqueira, V.B., Koch, O.P., Arisi, A.C.M., Fuzara, A.P., Azzalis, L.A., Barros, S.B.M., Cravero, A., Farre, S. and Videla, L.A. (1997) Regression of morphological alteration and oxidative stress-related parameters after acute lindane-induced hepatotoxicity in rats. Toxicology, 117: 199-205.

4. Pieroni, A., Howard, P., Volpato, G. and Santoro, R.F. (2004) Natural remedies and nutraceutical used in ethnoveterinary practices in Inland Southern Italy. Vet. Res. Commun., 28: 55-80.

5. Tariq, A.L. and Riyaz, A.L. (2013) Antioxidant activity of Camellia sinensis leaves. Int. J. Curr. Microbiol. Appl. Sci., 2(5): 40-46.

6. Nihal, A. and Hasan, M. (1999) Green tea polyphenols and cancer: Biological mechanisms and practical implications. Nutr. Rev., 57: 78-83.

7. Zhao, J.F., Zhang, Y.J. and Jin, X.H. (1999) Green tea protects against psoralen plus ultraviolet A-induced photochemical damage to skin. J. Invest. Dermatol., 113: 1070-1075.

8. Caliborne, A.L. (1985) Assay of catalase. In: Greenward, R.A., editor. Handbook of Oxygen Radical Research. CRC Press, Boca-Raton.

9. Marklund, S.L. and Marklund, G. (1974) Involvement of superoxide anion radical in the auto oxidation of pyrogallol and a convenient assay for superoxide dismutase. Eur. $J$. Biochem., 47: 496-474.

10. Rotruck, J.D., Pope, A.L., Ganther, H.E., Swanson, A.B., Hafeman, D.G. and Hekstra, W.G. (1973) Selenium, biochemical role as a component of glutathione peroxidase and assay. Science, 179: 588-590.

11. Snedecor, W.G. and Cochran, G.W. (1994) Statistical Methods. $6^{\text {th }}$ ed. Oxford and IBH Publishing Company, New Delhi. p258-268.

12. Padma, V.V., Baskaran, R., Shenoi, R.R. and Poornima, P. (2012) Quercetin attenuates lindane Induced oxidative stress in wistar rats. Mol. Biol. Rep., 39: 6895-6905.

13. Padma, V.V., Soumya, P., Felix, T., Bhaskaran, R. and Poornima, P. (2011) Protective effect of gallic acid against lindane induced toxicity in experimental rats. Food Chem. Toxicol., 49(4): 991-998.

14. Perrone, R.D., Madias, E. and Levey, A.S. (1992) Serum 
creatine as an index of renal function: New insights into old concepts. Clin. Chem., 38: 1933-1953.

15. Raheem, I.T.A., Sherbiny, G.A.E. and Taye, A. (2010) Green tea ameliorates renal oxidative damage induced by gentamycin in rats. Pak. J. Pharm. Sci., 23: 21-28.

16. Heikel, T.M., Mossa, A.T.H., Marei, G.I.K. and Rasoul, M.A.A. (2012) Cyromazine and Chloropyrifos induced renal toxicity in rats: The ameliorating effect of green tea extract. J. Environ. Anal. Toxicol., 2: 146-153.

17. Sahoo, A. and Chainy, G.B.N. (1998) Acute hexachlorocyclohexane-induced oxidative stress in rat cerebral hemisphere. Neurochem. Res., 23: 1079-1084.
18. Nasri, H., Ahmadi, A., Baradaran, A., Nasri, P., Hajian, S., Arian, A.P., Kohi, G. and Kopaei, M.R. (2014) Abiochemical study on ameliorative effect of green tea (Camellia sinensis) extract against contract media induced acute kidney injury. J. Renal Inj. Prev., 3(2): 47-49.

19. Fidan, A.F., Cigerci, H., Sozabilir, N.B., Kucukkurt, I., Yuksel, H. and Keles, H. (2008) The effects of the dose dependent $\gamma$-hexachlorocyclohexane (Lindane) on blood and tissue antioxidant defense systems, lipid peroxidation and histopathological changes in rats. J. Anim. Vet. Adv., 7 : $1480-1488$.

$* * * * * * * *$ 